IZA DP No. 4867

Home-Leaving Decisions of Daughters and Sons

Maria Concetta Chiuri

Daniela Del Boca

April 2010 


\title{
Home-Leaving Decisions of Daughters and Sons
}

\author{
Maria Concetta Chiuri \\ University of Bari \\ and CHILD \\ Daniela Del Boca \\ University of Turin, \\ Collegio Carlo Alberto, CHILD and IZA
}

Discussion Paper No. 4867

April 2010

IZA

P.O. Box 7240

53072 Bonn

Germany

Phone: +49-228-3894-0

Fax: +49-228-3894-180

E-mail: iza@iza.org

Any opinions expressed here are those of the author(s) and not those of IZA. Research published in this series may include views on policy, but the institute itself takes no institutional policy positions.

The Institute for the Study of Labor (IZA) in Bonn is a local and virtual international research center and a place of communication between science, politics and business. IZA is an independent nonprofit organization supported by Deutsche Post Foundation. The center is associated with the University of Bonn and offers a stimulating research environment through its international network, workshops and conferences, data service, project support, research visits and doctoral program. IZA engages in (i) original and internationally competitive research in all fields of labor economics, (ii) development of policy concepts, and (iii) dissemination of research results and concepts to the interested public.

IZA Discussion Papers often represent preliminary work and are circulated to encourage discussion. Citation of such a paper should account for its provisional character. A revised version may be available directly from the author. 
IZA Discussion Paper No. 4867

April 2010

\section{ABSTRACT}

\section{Home-Leaving Decisions of Daughters and Sons ${ }^{*}$}

In spite of relevant differences between countries, a common international pattern emerges: daughters leave parental homes earlier than sons. Drawing upon the European Community Household Panel, we explore the impacts of various factors that affect daughters' and sons' home-leaving decisions. Our results show important differences across genders as well as across countries. The decisions of daughters appear to be more responsive than sons' to family structure as well as to institutional factors such as the labor and the mortgage market.

JEL Classification: J2, C3, D1

Keywords: $\quad$ living arrangements, gender, social policies

Corresponding author:

Daniela Del Boca

Department of Economics

University of Turin

Via Po 53

10124 Turin

Italy

E-mail: dani.delboca@unito.it

\footnotetext{
* We thank Anna Laura Mancini and Salvatore Nunnari for excellent research assistance and three anonymous referees for useful suggestions on a previous draft. The paper was presented at Centro Dondena at Bocconi University and the Conference "The Household and the Labor Market" AIELCHILD-Labor at Collegio Carlo Alberto.
} 


\section{Introduction}

A general feature of transitions to adulthood in contemporary developed societies is that young adults tend to study longer, to enter the labor market, leave the parental home, cohabit, marry, and become parents later. Recent data show striking differences in the timing of leaving home for adult children across Europe. In Finland and Denmark, children leave the household between 18 and 22 after which a very negligible proportion still cohabit with their parents. At the other end of the spectrum, in Southern countries, a negligible proportion leaves the household between 18 and 22 and most of them remain home until 30. The so called "latest-late" pattern of transition to adulthood (Billari and Kohler, 2004) is linked to the rising age at which young adults complete their education and enter the labor market, leave home, form a union and give first birth. Given the similarities of human capital accumulation, one could expect that young women's transition to adulthood would not be different from that of young men. Recent analysis of education attainment by gender has shown in fact that women finish school earlier than men (Cammelli 2005).

In spite of the differences between countries, a common pattern emerges across countries studied: young women leave home earlier than men (2-3 years). The difference in age young adults that leave the parental home by gender can be certainly in part correlated to the difference in age at first marriage. However, the number of children leaving parental home at the time of the first union has declined and is more than 50 percent only in Southern Europe and less than 25\% in the North (Billari et al. 2001).

In our paper we aim to analyze gender differences in a comparative framework and explore whether and where institutional factors characterizing the labor market and the mortgagemarket have different impacts on daughters and sons' probability of leaving parental home. No research to our knowledge has specifically focused on these aspects. Given the differences in home leaving decisions across countries, we use the European Community Household Panel (ECHP henceforth), a large international dataset on households. We complement this information with indicators of local marriage, labor markets, mortgage markets imperfections and social expenditures invested in youth.

While other papers on home-leaving decisions have considered men and women separately in a tangential manner (Aasve et al (2001), Le Blanc and Wolff (2006), for us the gender differences are the primary focus. Relative to previous work, we explore this dimension by including in our empirical analysis also measures of labor market, mortgage market and youth policies 
characteristics. We find some important differences in these institutional effects on home-leaving across genders.

Why is it important to analyze home-leaving decisions separately for women and men? For women a late transition to adulthood implies a delay in cohabitation, marriage and fertility. Southern European countries have the highest median age at leaving home as well as the highest median age at parenthood, and fertility is among the lowest, with a clear trend towards further postponement. The average age at first birth is also important because it influences the total number of children a woman might have as well as the population size, and it may affect birth weight and birth defects.

For men a slower transition to adulthood may be also critical for the household division of labor, meaning that they accumulate little experience of sharing household chores with partners with potential effects on their wives' labor supply, career and fertility, especially in countries where child care services are less widespread and/ore more expensive (Esping Andersen et al., 2007). Recent time use data show that Southern European husbands contribute less to housework and the excessive burden on women and that can be considered strongly correlated with low fertility (Rosina, 2004).

The results of our empirical analysis show that men are more irresponsive than women to changes in labor and mortgage markets. The design of labor market policies that are intended to promote mobility (going where the jobs are, for example) may well wish to take into account these types of differences.

In Section 2 we review the recent literature and discuss the objectives and implications of our research. In Section 3 we describe the data set and the characteristics of the sample. In Sections 4 and 5, we present our econometric strategy and discuss the empirical estimates. Section 6 provides conclusive remarks.

\section{Recent literature}

A large number of studies analyzing adult children's living arrangements have explored the factors affecting the transition towards independent living. The seminal paper by Mc Elroy (1985) and other research has emphasized the role of the family as an insurance mechanism against employment risk. Parent's income can support children by supplying space and financial help within the parental house. They can also provide support them by transferring resources to allow their children to achieve an independent living arrangement. Parents' resources appear to be an important factor 
which affects the trade-off between living at home and living independently. Le Blanc and Wolff (2006) show positive effects of parents' income on homeleaving decision.

While parental resources are important in determining the trade-off between living at home or living independently, the institutional characteristics of the environment also play a role. The most important institution which may affect the independence of youths is the labor market. Card and Lemieux (2000) and Rosenzweig and Wolpin (1993) show that the probability of living with parents is higher among unemployed and low-income groups in Canada and the US. The family is also important in Southern Europe where unemployment rates are higher and the welfare state offers even less protection to the unemployed or less support to young job seekers (Becker et al., 2004).

Another important institution affecting the cost of adult children leaving the parental home has to do with the mortgage market. Martins and Villanueva (2006) show that limited access to mortgage markets explains why young adults live with their parents and differences in mortgage market imperfections within Europe can explain up to 20 percent of the cross- country variance of establishing a new household. Similar results emerge in research regarding individual countries: Ermisch (1999) for the UK, and Giannelli and Monfardini (2003) for Italy.

But being on their own may mean different things: children can choose to live alone, live with a friend or to get married. Another strand of the literature investigates the important role of the marriage market. As follows from theoretical models of marriage when women are scarce relative to men, i.e., a high sex ratio, there is an impact on labour supply, marriage and divorce (i.e., Grossbard and Amuedo Dorantes, 2007).

Another factor which may implicitly or explicitly favour home-leaving decisions is the welfare state. Esping Andersen (1999) has grouped countries with similar welfare states and shows that in Northern European countries (liberal and social democratic regimes) an early age of leaving home is the norm due to the generous support for youth. In contrast, a very late age prevails in the Southern European ones given that no welfare support to youth is provided.

Each of the welfare regimes is also strongly intertwined with the strength of family ties (Dalla Zuanna and Micheli 2004, Chiuri and Del Boca, 2008) ${ }^{1}$.

\footnotetext{
${ }^{1}$ According to Reher (1998), these differences have historical roots. The Northern European pattern of "weak family ties" and early transition to adulthood is linked to the medieval habit of leaving the parental home early for agricultural work or to become a servant. On the contrary, in Southern Europe, the "strong family ties" pattern was
} 
A less generous welfare state in the South is compensated for strong family ties, while a generous one in the North is associated with weak intergenerational ties. Aasve et al (2001), have shown that in social democratic welfare states, income and employment play a insignificant role for both daughters and sons. The contrary is true in countries where the welfare state is less generous.

In our empirical analysis we will further explore these differences, focusing on the impact of institutional factors such as mortgage and labor market and expenditures in youth policies on daughters and sons .

\section{Data description}

In our empirical analysis we use the ECHP, a longitudinal survey coordinated and supported by EUROSTAT. The survey involves a representative sample of households and individuals interviewed over eight years (1994-2001) in each of the 15 European countries (EU-15). The standardized methodology and procedure in data collection yield comparable information across countries, making the ECHP a unique source of information for cross-countries analyses at the European level. The unit of analysis of the ECHP is the family and, within the households, all individuals over 16. The ECHP has many advantages: it covers the whole population, it includes a wide variety of useful and harmonized information (for example number and age of children, or marital status) and it is possible to link household-level information to individual data.

The main question is how to make valid inference about population's parameters of interest when the data subject to unit nonresponse. Nicoletti and Peracchi (2002) find three main causes of survey nonparticipation in the ECHP: refusal to cooperate, contact failure and ineligibility. Their analysis of cross-country differences in survey participation rates tries to identify the role played by differences in the socio-demographic composition of national populations and in the characteristics of the data collection process. They find that several individual and household characteristics (such as number of children, the length of residence at the current address, home ownership and household income) have good predictive power

For our empirical analysis we select fourteen countries of the dataset, representative of the different geographical areas of Europe For the fourteen countries we consider all available waves, creating an unbalanced panel. We

characterized by extensive periods of co-residence parents and adult children, in some areas extending to the whole life. 
also select all households in which adult children are in the age range 18-34 and are observed living with parents for at least one wave. Table A.1 in the Appendix reports the age distribution of adult children in the ECHP as compared with our selected sample of children (coresiding with parents for at least one wave).

Figure 1 plots the coresidence pattern by age and gender, for each country, describing how gender differences in children's living arrangements are distributed along their life course. While behavioral discrepancies fade away in countries such as Denmark, the Netherlands, and the UK behavioral discrepancies, in others, such as Greece or Austria they persist longer.

The first group of variables that we consider regards personal characteristics: adult children's age and squared age, adult children's gender and a dummy variable controlling for tertiary education (college degree and above). Table 1 reports coresidence rates and the proportion of children with university degrees, by single country and gender. In all countries, coresidence rates are larger for men and in some, such as Denmark and Finland, the percentage of men coresiding is up to 10 percent higher than that of women.

However, the proportion of tertiary education reported in Table 1 is greater for women in most countries. The second group of variables includes parental characteristics. Several measures of income are included in the ECHP. We focus on annual incomes, rather than monthly incomes. All incomes relate to the year prior to the survey. ${ }^{2}$ To capture non linearities we include also a squared measure of fathers' income.

The third group of variables includes family composition: the number of siblings living in the household and the presence of grandparents. These variables may imply the need of provide more care giving responsability, but also more overcrowded living conditions. The average values reported for every selected variable show a wide heterogeneity across EU countries.

The information given by the ECHP dataset was augmented with additional information taken from various statistical sources. In particular, we consider a labor market indicator, computed on the basis of annual female and male unemployment rates defined at the regional level and a proxy for the local marriage market, i.e., the local sex ratio computed as the probability of finding a partner of the same age range in the region of residence (they

\footnotetext{
${ }^{2}$ The ECHP breaks down total income in three mutually exclusive categories, referred to as public income, work income, and private (non-work) income. The first category comprises in particular social insurance receipts, family allowances, and sickness or invalidity benefits. Work income refers to wage and salary earnings or self-employment income. Non-work private income includes private transfers from other household members.
} 
are both computed from the EUROSTAT REGIO dataset, years 1994-2001). We also examine the loan to value ratio, which measures the availability of mortgage finance by country. This is a measure of the conventional homepurchase loans to first-time buyers. Even though the loan to value ratio might have changed over a decade, we consider the average values for two decades, i.e. the 1990s and 2000s as reported in Chiuri and Jappelli (2003) and in Maclennan et al. (1998). The country average values for the three indicators are reported in Table 2, columns 1-3.

Following the standard time invariant grouping of the countries considered (Esping Andersen 1999), we combine them in four groups: Mediterranean countries (Italy, Greece, Portugal and Spain), Central West-European countries (Austria, Belgium, France, Germany, Luxembourg and the Netherlands), Northern Continental European countries (Denmark and Finland) and Northern non-continental European countries (the UK and Ireland). The four groups of European countries identify not only geographical contiguity, but also similar culture and welfare states. We also consider an alternative and time varying measure of the country welfare state. In particular, we include the annual youth social expenditures as the percentage of total public expenditures Computed on the basis of the OECD SOCX (2006), youth social expenditure includes housing, active labor market policies and policies for other contingencies related to youth such as income support programs. This proxy (Table 2, column 4) shows that Southern European welfare states are less oriented towards helping young people to start out and become economically independent when compared to Northen European countries.

\section{Methodological Framework}

In our model, the living arrangements of adult children are the outcome not only of personal and household characteristics, but also of variables related to the characteristics of the socio-economic and cultural environment in which the individual and the household live. While it is of interest to model children leaving and reentering the household, in this analysis we only consider the initial decision to leave the parental home given the extremely

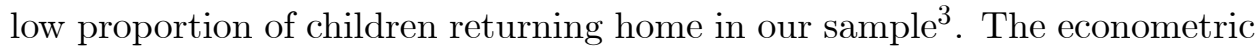
specification of the coresidence decision rule is assumed to be a quasi-reduced form representation of the solution to the individual child's optimization

\footnotetext{
${ }^{3}$ For an analysis of this phenomenon in the US see De Vanzo and Frances K. Goldscheider (1990), and Kaplan (2009).
} 
problem. As is common, a latent variable structure is assumed. Let the net value of co-residence with parents for an adult child in period $t$ be given by:

$$
L_{i, t}^{*}=H_{i, t} \beta_{1}+H H_{i, t} \beta_{2}+E_{i, t} \beta_{3}+I_{i, t} \beta_{4}+W_{i} \beta_{5}+u_{i, t},
$$

where $H_{i, t}$ is a row vector containing the observed variables measuring child $i$ 's human capital, age and gender at time $t$. $H H_{i, t}$ is the vector of household characteristics at time $t$ for child $i$, and includes variables such as the number of children in the household, the presence of grandparents, and parents' income. $E_{i, t}$ is the vector of variables describing the socio-economic environment (labor market characteristics, marriage market, the degree of financial market development, which is proxied by the down payment ratio) that child $i$ lives in at time $t$. The vector $E_{i, t}$ varies by country and year, but is the same for all individuals surveyed in a particular year and country. The last group of vectors are $I_{i, t}$ and $W_{i}$. The first one varies by the country that $i$ lives in and time $t$, and contains the youth social policy expenditure as a percent of total public expenditure. The $W_{i}$ vector is a set of dummy variables that delineates the four groups of countries. Finally, the term $u_{i, t}$ is a disturbance term, the distributional properties of which will be discussed below.

Define the (dependent) variable $d_{i, t}=1$ if $i$ coresides with his/her parents at time $t$, and set $d_{i, t}=0$ if not. Then we have that

$$
d_{i, t}=1 \Leftrightarrow L_{i, t}^{*}>0 .
$$

We assume that the disturbances can be written as follows:

$$
u_{i, t}=\eta_{i}+\varepsilon_{i, t}
$$

where $\varepsilon_{i, t}$ is independently and identically distributed as a logistic random variable for all $(i, t)$. We assume that the permanent component of each disturbance term, $\eta_{i}$, is potentially not independently distributed with respect to all of the observable characteristics included on the right hand side of its respective equation. Using the estimator that we employ, no assumptions need be made regarding $\eta_{i}$ except that it be time-invariant.

Our main interest lies in examining the impacts of the institutional environment, indicators of individual and family characteristics, as well as other factors assumed unobservable to the analyst. One of the limitations of the economic analysis of coresidence is, in fact, the omission of factors such as tastes, and other individual and family-specific traits -for example conflict, strictness and other important factors in explaining the decision to stay or 
leave home. Many, or most, of these individual-specific factors affecting the decision are unobservable to the researcher. Under our logistic specification of the disturbance $\varepsilon_{i, t}$, it is well known that the probability that child $i$ will coreside with his/her parents at time $t$ is given by

$$
p\left(d_{i, t}=1 \mid X_{i, t}, \eta_{i}\right)=\frac{\exp \left(X_{i, t} \beta+\eta_{i}\right)}{1+\exp \left(X_{i, t} \beta+\eta_{i}\right)}, i=1, \ldots, N ; t=1, \ldots, T ;
$$

where $X_{i, t}$ is the vector of all of the covariates associated with individual $i$ in period $t$ (this vector contains all of the sub-vectors discussed when we presented (1) and $\beta$ is a (unknown) conformable parameter vector.

We use a fixed effects logit estimator to consistently estimate a subvector of $\beta$, which consists of coefficients associated with variables in $X_{i, t}$ that vary over time for at least some inidividuals in the sample. Chamberlain (1980) defined a conditioning scheme that transforms the data in such a way that the terms $(\eta)$ are eliminated and the simultaneity problem is avoided. The outcome of this conditioning scheme is that the coefficients associated with time invariant characteristics cannot be identified. Other parameters will be identifiable, and will be robust with respect to any form of association between the observable heterogeneity (i.e., the variation on the manner in which the unobservable heterogeneity is related to observable heterogeneity. The estimator works off of timing variability. The conditioning scheme is to look at the relative likelihood of living with parents in period $t$ given that the individual lived with the parents in exactly one of the periods. Thus, only individuals who lived with parents in one of the periods are used to estimate the identified subvector of $\beta$. The benefit of this reduction in sample size is the ability to robustly estimate the identified subvector of $\beta$. The estimates are invariant with respect to the dependence between $\eta$ and the covariates.

For purposes of our analysis, this is an extremely attractive feature. We know that countries vary greatly in the proportion of adult children who live with their parents. Some of this differences may be accounted for in terms of differences in observable characteristics of the countries. Most of the differences will be produced by differences in the distribution of $\eta$ across countries, however. The different distributions of $\eta$ across countries will have no impact on our estimates of the identified subvector of $\beta$. By contrast, if we were to estimate a cross-section logit specification of the probability of living with ones parents, all parameter estimates would be inconsistent under this scenario. Even within a country as long as selection (or attrition) is a function of unobservable factors it would not matter for the consistency of our estimates. The cost of using this rather flexible estimation method is the inability to determine the effect of variables which do not vary over 
time on the probability of coresiding in any given period. From the point of view of conducting policy analysis, which typically requires having access to estimates of all behavioral parameters, this may be a problem.

The conditional logit estimator also makes it difficult to identify duration effects, so that we are limited in terms of how we can alter (1) to introduce something akin to duration dependence of the kind that would typically be included in a hazard specification. The estimator basically works off of differences in values of regressors over time. We have included the age of the child, so that in successive periods, the difference in age is 1 , and this "effect" is included in the constant term of the differenced specification. Individuals remaining at home would have their durations increase by a year each year, so linear (in the index function) duration dependence would also show up in the constant terms. In another paper, we have explored the fit of a duration model (a semi-parametric Cox model) (Chiuri and Del Boca, 2008)

\section{Empirical Results}

Table 3 shows the empirical results of the fixed effects logit model by gender. The negative coefficient on age appears to be larger and more significant for daughters. Having tertiary education is positive for both daughters and sons, whereas parental income is not statistically significant on either sex. Both variables describing the family structure, such as the number of siblings as well the presence of grandparents in the household, increase the likelihood of cohabiting with parents with larger impacts for daughters. The coefficients related to the labor and the mortgage market for housing are statistically significant but only for daughters while the remaining factors have similar effects.

In Table 4 and Table 5 we report the estimates by countries' groups. Table 4 reports the estimates for Northern countries (continental and non continental). Having tertiary education is statistically significant only for sons as well as fathers' income. Tertiary education increases the likelihood of cohabiting with parents, while greater family resources has the opposite effect. Another important impact related to the family structure is that the number of siblings increases the probability of remaining in the parental home only for daughters in both contexts, while the presence of grandparents has no significant impact, confirming the existence of weak intergenerational ties. In these contexts, the family plays a modest role in providing elderly care $^{4}$. Being in a more favorable marriage market increases daughters' like-

\footnotetext{
${ }^{4}$ In Northern countries where elderly coresidence with offspring is less prevalent, the
} 
lihood of leaving home in Northern continental countries. On the contrary, more difficult labor market conditions increase daughters' likelihood of remaining in the parental home. More generous social expenditure for youth increases the likelihood of leaving home in Northern non continental countries for both.

In the liberal regimes, home-leaving decisions depend more on individual and parental characteristics, in the socio-democratic regimes, where leaving home early is the norm, individual, parental and institutional factors are less significant, confirming previous results (Aasve et al 2001).

Table 5 reports the results for Central West and Mediterranean countries. The coefficients on individual characteristics are similar, In Mediterranean countries, the father's income coefficient appears to be different by gender: positive for sons and negative for daughters. In other words, having greater family resources encourage daughters to leave and sons to remain home. Another peculiarity in Mediterranean countries concerns family structure. Both the presence of siblings and that of grandparents implies a greater likelihood of coresidence with parents.

The nstitutional factors' impacts are more statistically significant for daughters in both contexts. The coefficient related to youth social expenditure is not significant, probably due to the lower levels of expenditures.

For each of the specifications estimated, we also conducted a log likelihood ratio test to determine the degree to which the impact of individual and institutional characteristics on the rate of home leaving differs by gender. Given the large sample size, it may be expected that statistically significant differences are likely to be found. However, if gender differences are only reflected in the constant term of the index function upon which the conditional logit estimator is based, this effect should be eliminated by the pseudo-differencing upon which the estimator is based. We found that in all specifications tested, there were significant gender differences. This indicates that there are significant differences (both statistically and behaviorally) in the effects of covariates on the home-leaving decisions of both sons and daughters. Gender filters the impacts of all of the covariates (even the commonly shared ones) on the likelihood of cohabitation.

We will now provide some explorative evidence on the relationship between living arrangements and economic well-being. In this simple descriptive analysis we compare the situation of those who have left home to the situation of those who have not. Figures $2 \mathrm{a}$ and $2 \mathrm{~b}$ show poverty rates by

well-being of the elderly is based on residential autonomy or on private or public nursing homes 
whether a young person is still living in the parental home by the age of 25 . Poverty rates among sons are indicated by the dark lines, whereas they are indicated by lighter lines for daughters. An individual in a given country is considered to be poor if household income is less than 60 percent of the contemporary median income of that country.

It appears that women who live on their own are on average poorer than their male counterparts, and the differences are smaller when they coahabit with parents. This is consistent with recent empirical evidence indicating that women may accept worse jobs than men in order to leave earlier (Cammelli 2005).

The differences across countries are consistent with the actual choices. In Southern European countries women faring worse when on their own, tend to leave home later than elsewhere.

However this cross country comparison does not take account that the two groups may have different characteristics or preferences, which may underlie a selection effect in the decision to leave home. Neverthless, this evidence is consistent with econometric results which control for several factors. Parisi (2008) has shown that leaving home is associated with a higher probability of having a low income in Southern European countries. This result may also be interpreted in light of the existing differences in strength of family ties across countries. In contexts with strong family ties, the family plays an important role in defending its members against the difficulties imposed by social and economic constraints and children may receive support and protection until they leave home. In areas with weak-family ties, where the value attributed to individualism tends to predominate, young adults leave home earlier (Aasve et al 2006).

\section{Conclusion}

We have explored the differences in leaving home of daughters and sons in relation with several important factors: individual characteristics, parental resources, family structure and institutional aspects. The relevance of these factors differs significantly by countries and genders.

While in Northern continental countries, home-leaving decisions do not appear to be largely related to economic variables, (parental income and institutional factors), these variables play a more important role in the other contexts. In Mediterranean countries parental income has actually opposite effects on daughters and sons: greater family resources is related to higher rates of leaving home for daughters and higher rates of cohabiting with 
parents for sons.

Confirming other gender differences, our results show that family structure appears to be more important for daughters in all contexts indicating persistence of traditional roles. In addition, sons tend to be more unresponsive than daughters to institutional factors. The design of labor market policies that are intended to promote mobility for example may want to take into account these types of differences.

Finally, the comparison between children coresiding with parents and living independently reveals that women on their own tend to fare worse than their male counterparts. In Southern European countries especially women faring worse when live independently are likely to leave home later than in other countries. The interpretation is that, in contexts where welfare support for the youth is less generous, and the labor and mortgage market is more limited, remaining in the parental home longer may lead to better educational and occupational outcomes.

\section{References}

[1] Aassve A., F. Billari, F., Mazzuco, S \& Ongaro, F.(2001). Leaving Home Ain't Easy. A Comparative Longitudinal Analysis of ECHP Data, MPIDR WP. 2001-038.

[2] Aassve, A., Iacovou M. \& Mencarini,L. (2006) Youth Poverty and Transition to Adulthood in Europe. Demographic Research, 15, pp 21-40.

[3] Becker, S., Bentolila, Fernandes, A. \& Ichino,A. (2005) Youth Emancipation and Perceived Job Insecurity of Parents and Children. IZA D.P. 1836.

[4] Billari, F. \& Kohler, H. (2004). Patterns of low and lowest-low fertility in Europe, Population Studies, 58(2):161-176

[5] Billari, F., Philipov \& P. Baizán Munoz. (2001).Leaving home in Europe: the experience of cohorts born around 1960," MPIDR Working Papers WP-2001-014..

[6] Cammelli A. (2005) La transizione dall'università al lavoro in Europa, Il Mulino.

[7] Card, D., \& Lemieux, T.(2000) Adapting to Circumstance: The Evolution of Work, School and Living Arrangements Among North American 
Youth, in Blanchflower D. and R. Freeman (eds.) Youth Employment and Joblessness in Advanced Countries, University of Chicago Press.

[8] Chiuri, M. C. \& D. Del Boca (2008). Household membership decisions of adult children. IZA DP 3546.

[9] Corijn, M. \& Klijzing, E. (Eds.) (2001) Transitions to Adulthood in Europe. European Association for Population Studies, Kluwer Academic Publishers, Dordrecht

[10] Chiuri, M. C., \& Jappelli T.(2003), Financial Market Imperfections and Home Ownership: a Comparative Study. European Economic Review $47,857-875$.

[11] Dalla Zuanna, G., \& Micheli,G (eds). (2004), Strong Family and Low Fertility: A Paradox?, Kluwer Academic Publishers, Dordrecht / Boston / London.

[12] Ermisch, J. (1999). Prices, parents and young people's household formation. Journal of Urban Economics, 42:1-17.

[13] Ermisch, J., \& Di Salvo P. (1997). The economic determinants of young people's household formation. Economica, 64, 627-644.

[14] Davanzo, J. F. \& Goldschieder, K.(1990) Coming home again:returns to the parental home of young Adults.Populations Studies 44, n,2 pp.241255.

[15] Esping-Andersen, G. (1999), Social foundations of postindustrial economies, Oxford University Press, Oxford.

[16] Esping Andersen, G. Brodman, S. \& Guell, M.,(2007) When fertility is bargained. Second births in Denmark and Spain, European Sociological Review, 23 (5). 2007.

[17] Giannelli G. \& Monfardini G. (2003) .Joint decisions on household membership and human capital accumulation of youths. The role of expected earnings and local markets, Journal of Population Economics, May, 16 (2): 265-285.

[18] Grossbard, S. Amuedo-Dorantes A.(2007).Cohort-Level Sex Ratio Effects on Women's Labor Force Participation Review of Economics of the Household, 5 (3), 249-278 
[19] Kaplan, G. (2009). Moving Back Home:Insurance Against Labor Market Risk" Mimeo NYU.

[20] Le Blanc, D. \& Wolff, C. (2006). Leaving Home in Europe: The Role of Parents' and Children's Incomes, Review of the Economics of the Household, issue 4, pp.53-73.

[21] Maclennan D., Muellbauer, J., \& Stephens, M.(1998). Asymmetries in housing and financial market institutions and EMU. Oxford Review of Economic Policy, 14 (3): 54-80.

[22] Martins, N. \& Villanueva, E. (2006). Does Limited Access to Mortgage Debt Explain Why Young Adults Live with their Parents? Working Papers 0628, Banco de Espana.

[23] McElroy, M. (1985). The Joint Determination of Household Membership and Market Work: The Case of Young Men", Journal of Labor Economics, 3 (3): 293- 316.

[24] Parisi, L.(2008). Leaving Home and the Chances of Being Poor: The Case of Young People in Southern European Countries. Labour 22 (Special Issue) 89-114 (2008)

[25] Reher, D. S. (1998).Family Ties in Western Europe Persistent Contrasts Population and Development Review vol 24 n.2 (Jun 1998) pp 203-234

[26] Rosenzweig, M. \& Wolpin, K. (1993) Intergenerational Support and the Life- Cycle Incomes of Young Men and Their Parents: Human Capital Investments, Coresidence, and Intergenerational Financial Transfers. Journal of Labor Economics, 11 (1): 84- 112.

[27] Rosina, A. (2004). "Family Formation and Fertility in Italy", in Dalla Zuanna, G., Micheli, G.A. (eds.), Strong Family and Low Fertility: A Paradox?, Kluwer Academic Publishers. 


\section{Table 1}

Average coresidence rate and university degree for adult children (aged 18-34)

\begin{tabular}{|c|c|c|c|c|}
\hline \multirow[t]{2}{*}{ Country } & \multicolumn{2}{|c|}{$\begin{array}{l}\text { Coresidence rate } \\
\text { (age 18-34) }\end{array}$} & \multicolumn{2}{|c|}{ Third level of education } \\
\hline & $M$ & $\mathrm{~F}$ & $M$ & $\mathrm{~F}$ \\
\hline Austria & 0.92 & 0.86 & 0.02 & 0.04 \\
\hline Belgium & 0.80 & 0.78 & 0.23 & 0.25 \\
\hline Denmark & 0.60 & 0.50 & 0.06 & 0.09 \\
\hline Finland & 0.68 & 0.60 & 0.06 & 0.11 \\
\hline France & 0.79 & 0.72 & 0.22 & 0.25 \\
\hline Germany & 0.79 & 0.70 & 0.07 & 0.06 \\
\hline Greece & 0.92 & 0.87 & 0.14 & 0.20 \\
\hline Ireland & 0.90 & 0.87 & 0.14 & 0.17 \\
\hline Italy & 0.90 & 0.87 & 0.06 & 0.08 \\
\hline Luxembourg & 0.87 & 0.84 & 0.13 & 0.09 \\
\hline Netherlands & 0.75 & 0.68 & 0.02 & 0.03 \\
\hline Portugal & 0.88 & 0.86 & 0.04 & 0.08 \\
\hline Spain & 0.89 & 0.86 & 0.22 & 0.28 \\
\hline U.K. & 0.71 & 0.63 & 0.43 & 0.46 \\
\hline
\end{tabular}

Note. Average coresidence rate is computed on the sample of adult children cohabiting with parents at least for one year. All waves are pooled. 
Table 2

Indicators of local marriage and labour markets by gender. Maximum loan to value ratio for national housing market and proxy for welfare state

\begin{tabular}{|c|c|c|c|c|c|}
\hline \multirow{2}{*}{ Country } & \multirow{2}{*}{$\begin{array}{c}\text { Average local } \\
\text { Sex ratio } \\
{[\mathrm{F} /(\mathrm{M}+\mathrm{F})] * 100}\end{array}$} & \multicolumn{2}{|c|}{$\begin{array}{c}\text { Average Local } \\
\text { Unemployment rate }\end{array}$} & \multirow[t]{2}{*}{$\begin{array}{l}\text { Maximum Loan To } \\
\text { Value ratio }\end{array}$} & \multirow[t]{2}{*}{$\begin{array}{c}\text { Youth social } \\
\text { expenditure (\%) }\end{array}$} \\
\hline & & $M$ & $\mathrm{~F}$ & & \\
\hline Austria & 49.35 & 3.14 & 4.63 & 80 & 3.47 \\
\hline Belgium & 49.22 & 6.71 & 10.32 & 80 & 6.57 \\
\hline Denmark & 49.08 & 4.29 & 5.83 & 80 & 11.71 \\
\hline Finland & 48.90 & 7.8 & 8.3 & 80 & 8.37 \\
\hline France & 49.53 & 7.86 & 11.38 & 80 & 9.03 \\
\hline Germany & 48.36 & 8.09 & 9.95 & 80 & 7.22 \\
\hline Greece & 48.28 & 4.67 & 11.38 & 75 & 5.86 \\
\hline Ireland & 49.41 & 8.42 & 8.17 & 80 & 14.28 \\
\hline Italy & 49.51 & 10.83 & 20.76 & 60 & 1.79 \\
\hline Luxembourg & 49.31 & 1.50 & 3.19 & 60 & 2.25 \\
\hline Netherlands & 49.14 & 3.05 & 4.97 & 75 & 10.07 \\
\hline Portugal & 49.65 & 3.15 & 4.78 & 80 & 4.64 \\
\hline Spain & 49.07 & 11.94 & 23.26 & 80 & 6.19 \\
\hline U.K. & 48.69 & 5.86 & 4.07 & 95 & 10.08 \\
\hline
\end{tabular}

Note. Average Sex Ratio computed as female population over total population by country regions from REGIO dataset (EUROSTAT), 1994-2001. Average unemployment rate from REGIO dataset refers to the same years and country regions. Maximum Loan-To-Value ratio is drawn from Chiuri and Jappelli (2003) and Maclennan, Muellbauer and Stephens (1998); it refers to the 1990 decade. Youth social expenditure as percentage of total public expenditure is from OECD SOCX database, it includes housing, active labor market policies and policies for other contingencies as income support programs; the values reported in the Table is a 1994-2001 average. 


\section{Figure 1}

\section{Individual countries co-residence profiles: gender differences}
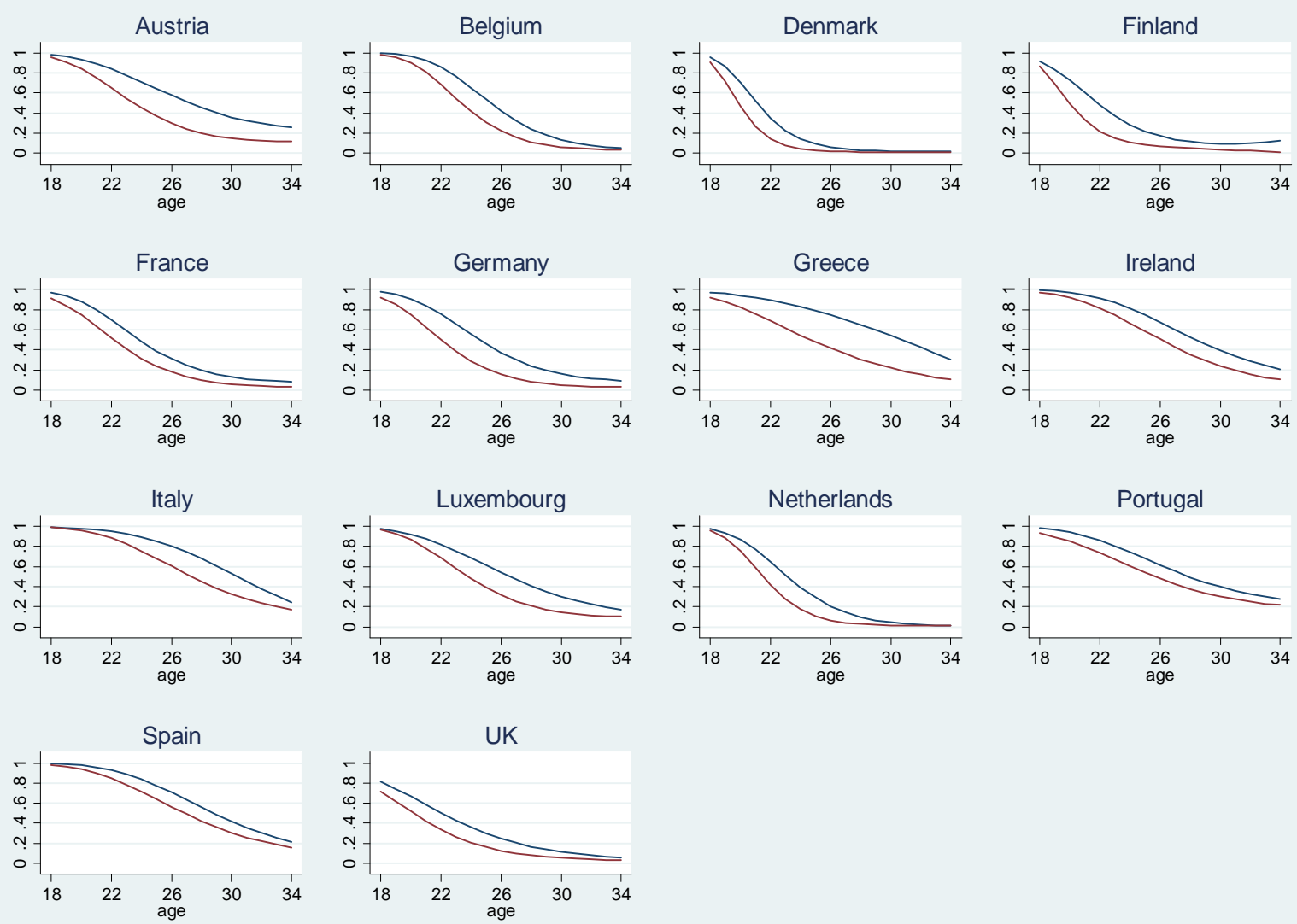

Note: In each graph the blue line describes men's co-residence pattern by age; the red line follows women's one. Each profile is obtained by the fitted values of a logistic regression of coresidence rate on a second-order age polynomial. 
Table 3

Conditional Fixed Effect Logistic Regression.

Dependent variable: coresident child (18-34 years old)- All countries

\begin{tabular}{|c|c|c|c|}
\hline & All sample & Sons & Daughters \\
\hline \multicolumn{4}{|l|}{ VARIABLES } \\
\hline \multirow[t]{2}{*}{ Age } & $-1.827 * * *$ & $-1.209 * *$ & $-2.348 * * *$ \\
\hline & $(0.230)$ & $(0.317)$ & $(0.343)$ \\
\hline \multirow[t]{2}{*}{ Age squared } & 0.001 & $-0.014^{*}$ & 0.008 \\
\hline & $(0.004)$ & $(0.006)$ & $(0.007)$ \\
\hline \multirow[t]{2}{*}{ Number of Siblings } & $0.817^{* *}$ & $0.382^{*}$ & $1.923 * *$ \\
\hline & $(0.269)$ & $(0.254)$ & $(0.454)$ \\
\hline \multirow[t]{2}{*}{ Education } & $1.068 * * *$ & $1.223 * * *$ & $0.968 * *$ \\
\hline & $(0.135)$ & $(0.195)$ & $(0.191)$ \\
\hline \multirow[t]{2}{*}{ Parental income } & -0.002 & -0.802 & -0.423 \\
\hline & $(0.370)$ & $(0.647)$ & $(0.568)$ \\
\hline \multirow{2}{*}{$\begin{array}{l}\text { Parental income } \\
\text { squared }\end{array}$} & 0.024 & 0.071 & -0.008 \\
\hline & $(0.017)$ & $(0.031)$ & $(0.026)$ \\
\hline \multirow[t]{2}{*}{ Grandparents } & $2.157 * *$ & $1.522 *$ & $3.242 * *$ \\
\hline & $(0.436)$ & $(0.537)$ & $(0.795)$ \\
\hline \multirow[t]{2}{*}{ Sexratio } & $0.002 *$ & $0.003 *$ & $0.002 *$ \\
\hline & $(0.001)$ & $(0.001)$ & $(0.001)$ \\
\hline \multirow{2}{*}{$\begin{array}{l}\text { Unemployment } \\
\text { rate }\end{array}$} & $0.059 *$ & 0.039 & $0.122 * *$ \\
\hline & $(0.028)$ & $(0.043)$ & $(0.0394)$ \\
\hline \multirow[t]{2}{*}{ Downpayment } & $0.002^{*}$ & 0.001 & $0.005 * *$ \\
\hline & $(0.01)$ & $(0.002)$ & $(0.002)$ \\
\hline \multirow[t]{2}{*}{ Youth Policies } & $-0.554 * * *$ & $-0.569 * * *$ & $-0.535 * *$ \\
\hline & $(0.080)$ & $(0.111)$ & $(0.119)$ \\
\hline Number of cases & 4240 & 2082 & 2158 \\
\hline
\end{tabular}

Standard errors in parentheses

*** $\mathrm{p}<0.01, * * \mathrm{p}<0.05, * \mathrm{p}<0.1$ 
Table 4- Conditional Fixed Effect Logistic Regression.

Per group of countries and gender - North Europe

\begin{tabular}{|c|c|c|c|c|}
\hline & (1) & (2) & (3) & (4) \\
\hline VARIABLES & $\begin{array}{l}\text { Northern non- } \\
\text { cont.countries- } \\
\text { Sons }\end{array}$ & $\begin{array}{l}\text { Northern non- } \\
\text { cont.countries- } \\
\text { Daughters }\end{array}$ & $\begin{array}{l}\text { Northern } \\
\text { cont.countries- } \\
\text { Sons }\end{array}$ & $\begin{array}{l}\text { Northern } \\
\text { cont.countries- } \\
\text { Daughters }\end{array}$ \\
\hline \multirow[t]{2}{*}{ Age } & -0.603 & $-1.474 * *$ & -1.738 & $-1.158 * *$ \\
\hline & $(0.559)$ & $(0.609)$ & (2.172) & $(0.734)$ \\
\hline \multirow[t]{2}{*}{ Age squared } & $-0.023 *$ & -0.0068 & -0.027 & 0.097 \\
\hline & $(0.011)$ & $(0.0131)$ & $(0.028)$ & $(0.063)$ \\
\hline \multirow{2}{*}{$\begin{array}{l}\text { Number of } \\
\text { Siblings }\end{array}$} & 0.270 & $1.893^{* *}$ & 3.396 & $3.703 *$ \\
\hline & $(0.258)$ & $(0.630)$ & (2.161) & $(1.556)$ \\
\hline \multirow[t]{2}{*}{ Education } & $1.149 * * *$ & 0.461 & $0.331 *$ & 0.643 \\
\hline & $(0.275)$ & $(0.270)$ & $(0.142)$ & $(1.966)$ \\
\hline \multirow{2}{*}{$\begin{array}{l}\text { Parental } \\
\text { Income }\end{array}$} & $-0.844 * *$ & -0.850 & $-0.246^{*}$ & -0.652 \\
\hline & $(0.199)$ & $(0.335)$ & $(0.107)$ & $(0.408)$ \\
\hline \multirow{2}{*}{$\begin{array}{l}\text { Parental } \\
\text { income } \\
\text { squared } \\
\end{array}$} & $0.647^{* *}$ & 0.095 & 0.132 & .299 \\
\hline & $(0.227)$ & $(.145)$ & $(0.525)$ & $(.188)$ \\
\hline \multirow[t]{2}{*}{ Grandparents } & 1.004 & -1.166 & & \\
\hline & (1.180) & (1.038) & & \\
\hline \multirow[t]{2}{*}{ Sexratio } & -0.002 & 0.007 & 0.013 & $-0.047 *$ \\
\hline & $(0.002)$ & $(0.030)$ & $(0.025)$ & $(0.020)$ \\
\hline \multirow{2}{*}{$\begin{array}{l}\text { Unemployment } \\
\text { rate }\end{array}$} & 0.029 & $0.448^{* *}$ & 0.465 & -0.897 \\
\hline & (0.099) & $(0.123)$ & $(0.768)$ & $(0.755)$ \\
\hline \multirow[t]{2}{*}{ Downpayment } & -0.003 & -0.004 & -0.003 & -0.002 \\
\hline & $(0.005)$ & $(0.006)$ & $(0.006)$ & $(0.002))$ \\
\hline \multirow[t]{2}{*}{ Youth policies } & $-.761^{* *}$ & $-1.507 * * *$ & -0.614 & -1.052 \\
\hline & $(0.248)$ & $(0.346)$ & $(0.956)$ & $(0.720)$ \\
\hline $\begin{array}{l}\text { Number of } \\
\text { cases }\end{array}$ & 333 & 293 & 201 & 203 \\
\hline
\end{tabular}

Standard errors in parentheses *** $\mathrm{p}<0.01,{ }^{* *} \mathrm{p}<0.05,{ }^{*} \mathrm{p}<0.1$ 
Table 5- Conditional Fixed Effect Logistic Regression.

Per group of countries and gender - South Europe

\begin{tabular}{|c|c|c|c|c|}
\hline & (1) & (2) & (3) & $(4)$ \\
\hline VARIABLES & $\begin{array}{l}\text { Central West } \\
\text { countries- } \\
\text { Sons }\end{array}$ & $\begin{array}{l}\text { Central West } \\
\text { countries- } \\
\text { Daughters }\end{array}$ & $\begin{array}{l}\text { Mediter. } \\
\text { countries- } \\
\text { Sons }\end{array}$ & $\begin{array}{l}\text { Mediter. } \\
\text { countries- } \\
\text { Daughters }\end{array}$ \\
\hline \multirow[t]{2}{*}{ Age } & $-2.428 * *$ & $-3.185^{* * *}$ & $-3.431 * *$ & $-2.836 * *$ \\
\hline & $(0.539)$ & $(0.517)$ & $(0.927)$ & $(1.033)$ \\
\hline \multirow[t]{2}{*}{ Age square } & 0.081 & $0.026^{* *}$ & -0.023 & 0.007 \\
\hline & $(0.010)$ & $(0.010)$ & $(0.016)$ & $(0.019)$ \\
\hline \multirow[t]{2}{*}{$\begin{array}{l}\text { Number of } \\
\text { Siblings }\end{array}$} & 0.669 & 1.546 & $2.352^{*}$ & $1.437^{*}$ \\
\hline & $(0.532)$ & $(1.117)$ & $(0.891)$ & $(.724)$ \\
\hline \multirow[t]{2}{*}{ Education } & $1.101^{* *}$ & $1.024^{* *}$ & 1.055 & $2.078^{* *}$ \\
\hline & $(0.331)$ & $(0.309$ & $(0.807)$ & $(0.577)$ \\
\hline \multirow[t]{2}{*}{ Parental Income } & 0.155 & 0.270 & $0.857^{*}$ & $-0.695 * *$ \\
\hline & $(0.134)$ & $(0.161)$ & $(0.348)$ & $(.1882)$ \\
\hline \multirow{2}{*}{$\begin{array}{l}\text { Parental Income } \\
\text { squared }\end{array}$} & -0.083 & -0.127 & $-0.407^{*}$ & $-0.298 * *$ \\
\hline & $(0.068)$ & $(0.091)$ & $(0.145)$ & $(0.077)$ \\
\hline \multirow[t]{2}{*}{ Grandparents } & 1.379 & 1.396* & $2.377^{*}$ & $4.077^{* *}$ \\
\hline & $(0.965)$ & $(.635)$ & $(0.977)$ & $(0.728)$ \\
\hline \multirow[t]{2}{*}{ Sexratio } & -0.002 & $0.003 *$ & .008 & $0.0059 *$ \\
\hline & $(0.001)$ & $(0.001)$ & $(0.055)$ & $(0.018)$ \\
\hline \multirow{2}{*}{$\begin{array}{l}\text { Unemployment } \\
\text { rate }\end{array}$} & -0.041 & $0.156^{*}$ & $0.392 *$ & $0.140^{*}$ \\
\hline & $(0.071)$ & $(0.062)$ & $(0.125)$ & $(0.054)$ \\
\hline \multirow[t]{2}{*}{ Downpayment } & 0.004 & $0.020^{*}$ & 0.007 & $0.002 *$ \\
\hline & $(0.003))$ & $(0.007))$ & $(0.010)$ & $(0.001)$ \\
\hline \multirow[t]{2}{*}{ Youth policies } & -0.296 & 0.043 & 0.357 & -0.033 \\
\hline & $(0.200)$ & $(0.226)$ & $(0.262)$ & $(0.028)$ \\
\hline Number of cases & 1180 & 1194 & 444 & 495 \\
\hline
\end{tabular}

Standard errors in parentheses *** $\mathrm{p}<0.01,{ }^{* *} \mathrm{p}<0.05, * \mathrm{p}<0.1$ 
Figure 2a

Poverty rate for young adults independently living till the age of 25, observed at later years (26-34)

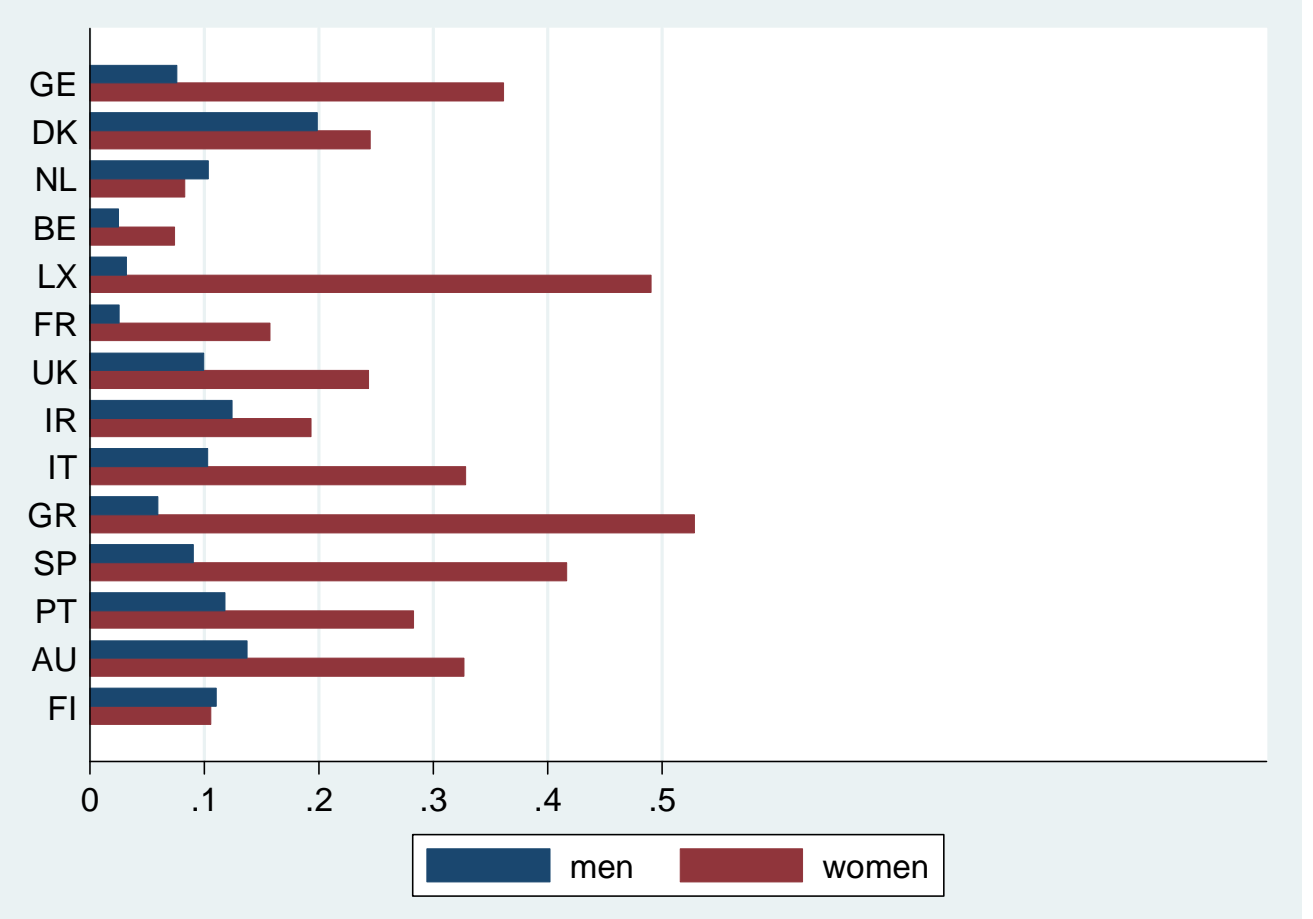

Figure 2b

Poverty rate for young adults coresiding with parents till the age of 25 , observed at later years (2634)

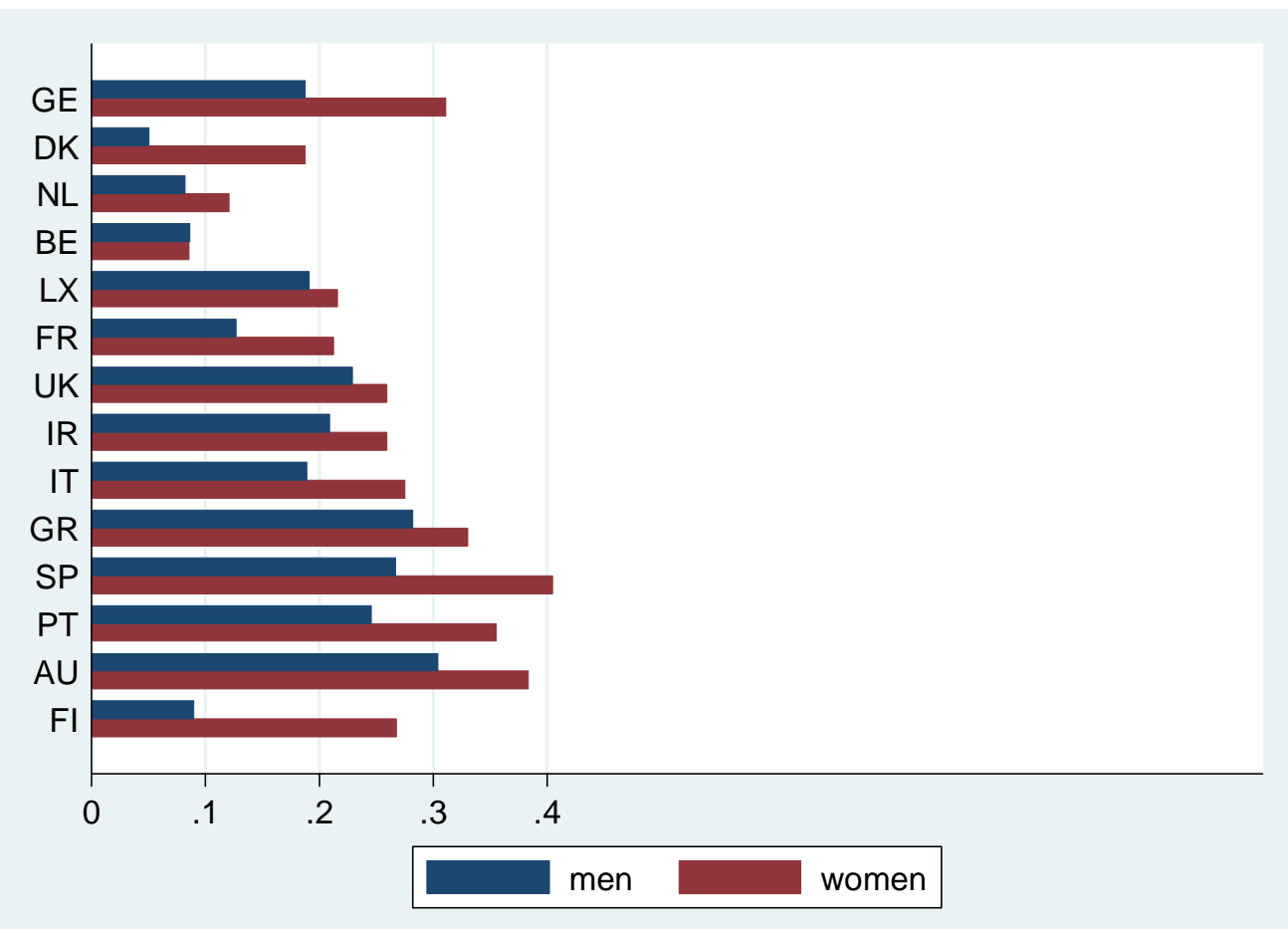




\section{Appendix}

Table A.1. Comparison by age of total 18-34 sample of adult children and sample of those coresiding at least for one wave.

\begin{tabular}{|c|c|c|c|c|c|c|}
\hline Country & & $18-19$ & $20-24$ & $25-29$ & $30-34$ & No of obs. \\
\hline \multirow[t]{2}{*}{ Austria } & ECHP sample & 5.86 & 11.85 & 28.22 & 54,07 & 11,476 \\
\hline & Coresid.for $1+y r$ & 8.80 & 20.15 & 37.93 & 33.92 & 6,054 \\
\hline \multirow[b]{2}{*}{ Belgium } & ECHP sample & 5.56 & 10.32 & 26.09 & 58.03 & 12,378 \\
\hline & Coresid.for $1+y r$ & 9.39 & 20.99 & 42.22 & 27.40 & 5,749 \\
\hline \multirow[b]{2}{*}{ Denmark } & ECHP sample & 4.66 & 9.74 & 26.78 & 58.81 & 10,955 \\
\hline & Coresid.for $1+y r$ & 12.21 & 28.21 & 44.74 & 14.74 & 2,964 \\
\hline \multirow[b]{2}{*}{ Finland } & ECHP sample & 7.72 & 15.29 & 28.87 & 48.12 & 12,312 \\
\hline & Coresid.for $1+y r$ & 13.51 & 30.46 & 40.56 & 15.47 & 5,131 \\
\hline \multirow[b]{2}{*}{ France } & ECHP sample & 5.83 & 11.34 & 29.88 & 52.96 & 29,659 \\
\hline & Coresid.for $1+y r$ & 9.89 & 22.11 & 43.39 & 24.61 & 13,216 \\
\hline \multirow[b]{2}{*}{ Germany } & ECHP sample & 4.93 & 9.64 & 25.11 & 60.32 & 31,260 \\
\hline & Coresid.for $1+y r$ & 9.26 & 20.78 & 38.78 & 31.18 & 13.181 \\
\hline \multirow[b]{2}{*}{ Greece } & ECHP sample & 6.37 & 12.27 & 29.36 & 52.00 & 24,899 \\
\hline & Coresid.for $1+y r$ & 8.06 & 17.64 & 36.60 & 37.70 & 15,728 \\
\hline \multirow[b]{2}{*}{ Ireland } & ECHP sample & 8.04 & 15.31 & 32.85 & 43.80 & 17,255 \\
\hline & Coresid.for $1+y r$ & 9.04 & 21.53 & 41.66 & 27.76 & 11,281 \\
\hline \multirow[b]{2}{*}{ Italy } & ECHP sample & 5.12 & 10.79 & 30.08 & 54.01 & 39,868 \\
\hline & Coresid.for $1+y r$ & 6.07 & 14.67 & 38.06 & 41.19 & 28,388 \\
\hline \multirow[b]{2}{*}{ Luxemb. } & ECHP sample & 3.85 & 8.16 & 26.38 & 61.61 & 11,621 \\
\hline & Coresid.for $1+y r$ & 5.95 & 15.20 & 37.64 & 41.22 & 5,477 \\
\hline \multirow[b]{2}{*}{ Netherlands } & ECHP sample & 5.26 & 9.21 & 23.43 & 62.09 & 20,038 \\
\hline & Coresid.for $1+y r$ & 12.43 & 26.05 & 42.89 & 18.63 & 6,153 \\
\hline \multirow[b]{2}{*}{ Portugal } & ECHP sample & 6.51 & 13.46 & 33.28 & 46.74 & 24,315 \\
\hline & Coresid.for $1+y r$ & 7.86 & 18.40 & 40.66 & 33.08 & 16,186 \\
\hline
\end{tabular}




\begin{tabular}{|l|l|c|c|c|c|c|}
\hline \multirow{3}{*}{ Spain } & ECHP sample & 5.62 & 12.09 & 30.90 & 51.39 & 38,038 \\
\cline { 2 - 7 } & Coresid.for 1+yr & 6.77 & 16.63 & 39.43 & 37.17 & 26,053 \\
\hline \multirow{3}{*}{ U.K. } & ECHP sample & 4.88 & 10.89 & 28.44 & 55.80 & 23,163 \\
\cline { 2 - 7 } & Coresid.for 1+yr & 9.89 & 21.79 & 41.66 & 26.66 & 7,917 \\
\hline
\end{tabular}

